\title{
Generative Fathering and the Dynamics of Connection between Fathers and Their Children
}

\author{
Sean E. Brotherson \\ North Dakota State University--Fargo \\ David C. Dollahite \\ Brigham Young University, david_dollahite@byu.edu \\ Alan J. Hawkins \\ Brigham Young University - Provo, hawkinsa@byu.edu
}

Follow this and additional works at: https://scholarsarchive.byu.edu/facpub

Part of the Other Social and Behavioral Sciences Commons

\section{Original Publication Citation}

Brotherson, S. L., Dollahite, D. C., \& Hawkins, A. J. (2005). Generative fathering and the dynamics of connection between fathers and their children. Fathering: A Journal of Theory, Research, and Practice About Men as Fathers, 3, 1-25.

\section{BYU ScholarsArchive Citation}

Brotherson, Sean E.; Dollahite, David C.; and Hawkins, Alan J., "Generative Fathering and the Dynamics of Connection between Fathers and Their Children" (2005). Faculty Publications. 4220.

https://scholarsarchive.byu.edu/facpub/4220

This Peer-Reviewed Article is brought to you for free and open access by BYU ScholarsArchive. It has been accepted for inclusion in Faculty Publications by an authorized administrator of BYU ScholarsArchive. For more information, please contact ellen_amatangelo@byu.edu. 


\title{
Generative Fathering and the Dynamics of Connection between Fathers and Their Children
}

\author{
SEAN E. BRotherson \\ North Dakota State University
}

\author{
David C. Dollahite \\ Brigham Young University
}

\author{
Alan J. Hawkins \\ Brigham Young University
}

\begin{abstract}
This study focused on examining narrative accounts told by fathers about how they connect with and care for their children. Qualitative, in-depth interviews were conducted with 16 fathers concerning their relationships with at least two of their children, including one child with special needs. The fathers' stories were recorded and the narratives were then explored to develop a better understanding of themes and behaviors by fathers related to the dynamics of connecting with their children. Coding and analysis of the fathers' personal narratives demonstrated specific patterns related to the concept of connection in a conceptual ethic of generative fathering. Findings were used to further understand the dynamics of connection between fathers and children and also addressed implications for theory, research, and practice related to fathering.
\end{abstract}

Keywords: generative fathering, fathering, fathers and children, connection, father-child connection

What is good fathering? Recent research on parenting in family studies has addressed the significance of a quality father-child relationship in a child's development in several ways (Biller, 1993; Lamb, 1981, 1997; Pruett, 1989; Snarey, 1993). Although some have questioned the importance of the father-child relationship (Harris, 1998; Silverstein \& Auerbach, 1999), a variety of research suggests that children

Correspondence concerning this article should be sent to Sean E. Brotherson, EML 277, Department of Child Development and Family Science, North Dakota State University, Fargo, ND 58105. Electronic mail: sbrother@ndsuext.nodak.edu.

Fathering, Vol. 3, No. 1, Winter 2005, 1-28.

(C) 2005 by the Men's Studies Press, LLC. All rights reserved. 


\section{BROTHERSON et al.}

who do not experience a father's meaningful relational influence may be at increased risk for challenges ranging from substance abuse to school failure to delinquency (Blankenhorn, 1995; Comanor \& Phillips, 1998; Harper \& McLanahan, 1998; Horn, 1999; Popenoe, 1996; Snarey, 1993).

Some scholars have suggested that attention to the needs of children is the primary factor for understanding and encouraging good fathering (Doherty, Kouneski, \& Erickson, 1998; Dollahite \& Hawkins, 1998; Popenoe, 1996). Dollahite, Hawkins, and Brotherson (1997) built on work by Snarey (1993) and others to develop the concept of generative fathering to describe fathering that responds readily and consistently to a child's developmental needs over time. The importance of fathering that focuses on loving and supporting children has been judged by some to be the most pressing social concern in contemporary American family life (Blankenhorn, 1995; Popenoe, 1996). Summarizing his intensive research on generativity among fathers, Snarey (1993) asserts, "Good fathering, it seems, really does matter. It matters over a long time, over a lifetime, and even over generations" (p. 356). While research has suggested that quality fathering does matter to the identity and well-being of both men and children developmentally, the patterns of how men care for children and those themes and behaviors that seem most important to men in the work they do as fathers are still being discovered. This study utilizes the conceptual ethic of generative fathering as a theoretical framework to present research that examines narrative accounts told by fathers about how they connect with and care for their children.

While fatherhood as a topic has been the focus of much scholarly and media attention in recent years (Biller, 1993; Blankenhorn, 1995; Doherty et al., 1998; Popenoe, 1996; Snarey, 1993), there still exists only a minimal amount of qualitative, in-depth research on the caring behavior of fathers. The need for additional research and new perspectives on fathering has been emphasized in recent scholarship (Day \& Lamb, 2003; Doherty, 1991; Hawkins \& Dollahite, 1997a; Levant, 1992). Scholars have realized that fathering must be understood in its own context and not simply as an adjunct to maternal caregiving. Thompson and Walker (1991) have noted, "Once women and men become parents, they tend to do different things with and for their children and relate to their children in different ways" (p. 91). This insight suggests the complexity that underlies the experience of parenthood for both mothers and fathers and the importance of understanding the unique and similar aspects of the parental experience for men and women. Much early research on the experience of fathers was obtained through gathering information from wives and children (Seward, 1994), thus making it likely that fathers' parental experience would be likened to that of mothers. More recent research on the competency of men in caring for children has provided wide-ranging and significant evidence that fathers are often capable and sensitive in giving care, responsive to children's concerns, and emotionally connected with their children (Biller, 1993; Gerson, 1993; Parke, 1996; Pruett, 1989). The trend is toward more careful investigation and increased appreciation for the variety and complexity of men's fathering experience (Doherty et al., 1998; Palkovitz, 1997), somewhat mirroring the pattern that feminist scholars have noted in research on mothering (Ferree, 1991; Thompson \& Walker, 1991).

Also lacking in the research literature has been a solid conceptual foundation upon which to base an understanding of men's experience as fathers. Doherty et al. 
(1998) suggested that the "fathering literature has been long on empirical studies and short on theory" (p. 284). A four-factor model of father involvement was introduced by Lamb and Pleck in the mid-1980s (Lamb, Pleck, Charnov, \& Levine, 1985), and Marsiglio (1995) reviewed fathering studies that primarily utilized life course theory, social scripting theory, and social identity theory as the main theoretical sources of reference. More recent efforts to develop conceptual frameworks to understand fathering have included a systems model (Parke, 1996) and a conceptual framework of responsible fathering (Doherty et al., 1998). Additional work has attempted to expand upon the Eriksonian model of development in a way that furthers theoretical insight into fatherhood, beginning with Snarey (1993) and followed by Dollahite et al. (1997).

Dollahite and Hawkins (1998) have described their conceptual ethic of generative fathering as "a nondeficit perspective of fathering rooted in the proposed ethical obligation for fathers to meet the needs of the next generation" (p. 110). It represents an effort to advance a broader conceptual framework that rests in a lifespan developmental perspective and also captures the strengths and potential of fathers. In this way it moves beyond many prior conceptual efforts that have generally narrowed the definition of "caring activity" too much or have arisen largely from a "deficit perspective" of men in families (Doherty, 1991; Hawkins \& Dollahite, 1997b; Palkovitz, 1997). This study employs the conceptual ethic of generative fathering as a theoretical lens to understand a specific domain of men's care of children, the relationship work of fathering, from a perspective that centers on men's strengths rather than their deficiencies as providers and caregivers. Because the generative framework focuses on how fathers can meet the fundamental and universal needs of children (Dollahite \& Hawkins, 1998), fathers interviewed for the study were asked to share stories about their experiences in caring for at least two children, including one child with special needs. This was done to ensure that fathers would be able to talk about meeting the needs of children at various ages and across varying circumstances, and it was expected that fathering a special needs child would elicit more examples of needs-based caring experience (Brotherson \& Dollahite, 1997). Fathers' narrative accounts are explored to illustrate particular ways in which men may connect with their children to foster better relationships. This study was developed to allow fathers to speak within their own frame of reference and provides a basis for furthering our knowledge about the dynamics of connection between fathers and their children.

\section{A CONCEPTUAL ETHIC OF GENERATIVE FATHERING}

Scholarship on fathering has illustrated that men bring important capacities to parenting and can make valuable contributions to a child's development and well-being, stimulating new advances in theoretical work about fathering (Biller, 1993; Lamb, 1997; Snarey, 1993). Dollahite et al. (1997) introduced a positive, growth-promoting conceptual model that seeks to "transcend the deficit model of men in families" (Hawkins \& Dollahite, 1994, p. 775). It has been described as a "conceptual ethic of generative fathering" that may describe reality but is intended "mainly to suggest what is possible and desirable" (Dollahite \& Hawkins, 1998, p. 111). The model builds on Erikson's concept of generativity in lifespan developmental theory and 


\section{BROTHERSON et al.}

also incorporates a contextual emphasis, suggesting that good fathering is "generative work" (Dollahite \& Hawkins, 1998; Dollahite et al., 1997).

Basic assumptions that underlie this model of fathering as generative work include the concept of generational ethics, the place of men's responsibilities and capabilities as fathers, and the "calling" of fathering as work in the context of care and nurturance (Dollahite et al., 1997). The model reflects what Doherty et al. (1998, p. 278) have termed "a more explicit value-advocacy approach" in theorizing and research about fathering (see Marsiglio, Amato, Day, \& Lamb, 2000). Generative fathering is thus defined as "fathering that meets the needs of children by working to create and maintain a developing ethical relationship with them" (Dollahite \& Hawkins, 1998, p. 111). The needs of children and the parent-child relationship establish a set of interrelated factors that affect the generative context.

The metaphor of generative "work" in relation to fathering suggests a linkage between familial relationships and labor and expands the concept of family work to include those activities that connect generations, instill values, increase affection, and provide for mutual support (Ahlander \& Bahr, 1995; Dollahite et al., 1997). Generative work is developmental work for fathers that "is a practical ideal combining activity and personal character" (Ahlander \& Bahr, 1995, p. 64); it builds both better men and better children. In the generative model, one of the fundamental conditions involving the needs of children is the interdependence between parent and child, and it is this context that gives rise to the corresponding domain of relationship work that fathers engage in with their children.

Relationship work in generative fathering is one of seven complementary domains of necessary generative work in the model (other domains include ethical, development, recreational, spiritual, economic, and mentoring work), and is focused on meeting the needs of children that arise from the interpersonal and emotional interdependence of father and child in the social environment (Dollahite \& Hawkins, 1998). Interdependence is seen as a fundamental condition of father-child interaction. The ethic of generative fathering proposes that a vital element in this interdependent relationship includes facilitating healthy attachments with children or simply connecting with the child in a supportive, lasting relationship.

Relationship work is suggested as a vital domain of the father-child relationship because human meaning and the formation of identity do not occur apart from a relational context with others (Berger \& Kellner, 1994; Erikson, 1959). Relationship work is important because "only through daily care, and in sustained emotional engagement in their children's lives, do fathers and mothers become parents in the generative sense" (Daniels \& Weingarten, 1982, p. 161). A child is born into the world with many kinship connections: father, mother, sibling, grandparent, aunt, cousin, etc. Families are organized systems and subsystems of relationships among differing family members, including fathers and children, and the quality of the father-child relationship is linked with the well-being of a growing child (Brotherson, Yamamoto, \& Acock, 2003; Snarey, 1993). The generative fathering framework affirms the importance of the father-child relationship by suggesting that most fathers have both the capacity and the responsibility to build positive, healthy relationships with their children. 
Connecting with one's child in relationship work involves both the sense of feeling emotionally and psychically connected with a son or daughter and the father's efforts to create and maintain healthy bonds between the child, himself, and others in the child's environment. The foundations for connecting with a child develop from birth as parents respond to a child's needs for safety, food, and protection and thus form an attachment bond that motivates care of the child (Ainsworth, 1973; Ainsworth, Blehar, Waters, \& Wall, 1978; Bowlby, 1982; Bretherton, 1987). The benefit of this attachment bond in encouraging responsiveness to a child's needs is suggested by Bretherton, who points out that "the mere knowledge that an attachment figure is available and responsive provides a strong and pervasive feeling of security and so encourages the person to value and continue the relationship" (1985, p. 6). Research on attachment suggests that fathers and children can establish this bond in the early years and the connection formed tends to be stronger as more time is spent together (Grossman et al., 1988; Marsiglio, 1991; Palkovitz, 1985). Lamb, Pleck, Charnov, and Levine $(1985,1987)$ pioneered research on the importance of paternal involvement with children, and continuing research has confirmed that fathers who connect with children in positive ways facilitate healthier child outcomes (Koestner, Franz, \& Weinberger, 1990; Lamb, 1997; Pleck, 1997; Snarey, 1993). Some important elements of paternal interaction that foster healthy connections with children include one-on-one engagement, availability to the child, and responsibility for some childcare management (Marsiglio, 1991). Both fathers and children seem to benefit from the positive development of these early ties (Palkovitz, 1985; Lamb, 1997), and a warm, connected relationship between fathers and children also seems critical throughout the child's school years and adolescence (Amato, 1987; Hosley \& Montemayor, 1997; Mosley \& Thomson, 1995). Barber $(1992 ; 1997)$ has documented the sense of connection between a parent and adolescent child as one of three critical factors of influence in the parent-adolescent relationship, supporting an adolescent's need for stability and social support. Since fathering occurs in the context of other family relationships, facilitating the child's connection with other family members and providing support to those relationships is also an important contribution fathers can make in their generative efforts (Cummings \& O'Reilly, 1997; Doherty et al., 1998).

Theoretically, the linkages between connection as a component of generative work in fathering and other constructs such as father presence, attachment, or elements of father involvement are still developing (Bowlby, 1982; Krampe \& Fairweather, 1993; Lamb et al., 1985). These other constructs benefit from a rich theoretical and empirical history, while the concept of connection in the generative fathering framework is relatively young and still developing. However, exploration of its dimensions is consistent with recent appeals to find more diverse and inclusive ways of examining the multiple features of father involvement (Hawkins \& Palkovitz, 1999). The three-pronged father involvement model pioneered by Lamb et al. (1985) has more recently undergone conceptual refinement toward a construct of "positive paternal involvement" (Pleck, 1997), which involves examination of specific patterns that reflect a father's positive involvement efforts. Pleck (1997) identifies positive paternal involvement as akin to components of generative fathering and suggests a need for further exploration of linkages between these concepts. 


\section{BROTHERSON et al.}

Krampe's (2003) recent work on the "inner father" focuses inward on the psychological aspects of the father-child relationship, but also suggests "at the interpersonal level, the inner father activates the need to belong in a drive for empathic relatedness with others that is intimate, inclusive, and directs the individual toward meaningful involvement with others" (p. 144). These different constructs suggest there are both external, observable aspects and internal, meaning-oriented aspects of father-child relationships. They also suggest a continuing response to the suggestion that father involvement is a "much richer and deeper construct than typical operationalizations suggest" (Hawkins, Bradford, Palkovitz, Christiansen, Day, \& Call, 2002, p. 183). A recent quantitative study examining connection between fathers and adolescent children furnished substantive evidence that it is an important influence in father-child relationships; however, it did not deeply articulate conceptual dimensions of the construct. Instead, it recognized that "specific dimensions of how fathers connect with children ought to be of primary concern" and that there is much "room for continued conceptualization and research of connection between fathers and children" (Brotherson, Yamamoto, \& Acock, 2003, p. 207).

This study describes a relatively small sample of fathers that is largely homogeneous in nature, although their fathering experiences vary according to the child's age and circumstances. The goal for this study is to generate understanding of how fathers describe their efforts to connect with their children and the meanings that their stories contribute to understanding the fathering experience (Gilgun, Daly, \& Handel, 1992). The study's purpose is thus not necessarily to generalize the results presented here to all fathers but to provide a window into how some fathers describe their own experiences in connecting with their children.

\section{METHODS}

A qualitative research design was utilized for the study in order to allow exploration of fathers' own descriptions of their efforts in generative fathering. Although qualitative research cannot be easily categorized, this project attempted to be inclusive of and bridge two genres of qualitative research identified by Tesch (1990): research that aims at "the comprehension of the meaning of text/action" and research that focuses on "the discovery of regularities" (pp. 59-60). It should be noted that there is no stark line between these areas; rather they complement and overlap one another. The first genre borrows from the phenomenological approach to research and links to Daly's (1995) description of qualitative research as an attempt "to capture the complex assumptions, meanings, and contradictions that enter into the process of experiencing and constructing the fatherhood [experience]" (p. 27). The second genre focuses on building an understanding of patterns that fathers describe in their narratives about fathering and generating theoretical concepts with heuristic utility, a common feature of the "constant comparative method" of qualitative research and analysis (Glaser \& Strauss, 1967). This study focused on collecting narrative accounts from fathers describing their experiences in connecting with their children, following Widdershoven's (1993) assertion that "the meaning of life cannot be determined outside of the stories told about it" (p. 2). Specifically, narrative accounts were defined as "the stories people tell about their own experiences, along 
with the meanings they attach to those stories" (Dollahite, Hawkins, \& Brotherson, 1996 , p. 350). Narrative has become an increasingly useful approach in qualitative research for understanding family life, and this study contributes to a growing body of research that employs this approach to understanding fathering (Brotherson \& Dollahite, 1997; Dienhart \& Dollahite, 1997; Dollahite, 2003a, 2003b; Marks \& Dollahite, 2001).

Sample participants in this study were selected as a convenience sample from a larger sample of families involved in a study of families who have children with special needs, while a number of other participants were recruited through purposive sampling techniques. Purposive sampling was utilized only to expand the number of participants beyond the convenience sample and to include additional fathers who had at least one child with special needs. Participants in the study consisted of 16 married fathers chosen from among a population of families in central Utah with at least one disabled child, some of whom were also involved in a local support program for such families. The participants were mainly Caucasian men of low to moderate socioeconomic status, ranging in age from their late 20 s to middle 40 s, and usually with two to three children. Participants also included one African-American father and one Chinese father. The children that fathers were interviewed about ranged in age from a few months to late adolescence, but the majority of these children were in early and middle childhood. Thus the study focuses primarily on fathers connecting with younger children. Due to a unique feature of the area in which interviews were conducted, nearly all of the participants were members of the Church of Jesus Christ of Latter-day Saints (Mormon). Each father was interviewed about relationships with at least two of his children, one of whom had special needs and one or more who did not.

The unique features of the sample result from its highly homogeneous nature (largely Caucasian and from a specific religious group) and the context of the participants' fathering experience (at least one child with special needs). These features suggest that the findings to be discussed are not highly generalizeable. Again, the goal of the study is focused on gaining insight into fathers' experience rather than generating generalizeable results. A rationale for selecting fathers with at least one special needs child was that this circumstance would elicit more intensive needs for care in the parent-child relationship, thus providing a potentially greater variety of both positive and negative examples of paternal care (Brotherson \& Dollahite, 1997). Another consideration related to the homogeneity in religious background of participants is that the Latter-day Saint faith places a high priority on family life and encourages fathers' involvement with and care for children (Dollahite, Marks, \& Olson, 1998; Hawkins, Dollahite, \& Rhoades, 1993). Thus, it may be that fathers in this sample are influenced both by context (special needs) and religious motivation in their parenting. Yet, as with other fathers, they are influenced by a wide variety of additional factors that carry equal or even greater influence on their behavior (Doherty et al., 1998).

Prior to the actual collection of personal narratives from study participants, interview questions were developed and detailed training for conducting qualitative indepth interviews was given to interviewers. The interviewing teams consisted of graduate-level students and faculty researchers who participated in a semester-long 
research seminar related to the study. Training included gaining familiarity with interview questions and procedures and assessing ethical issues. Sixteen fathers participated in the study, and each was first contacted by phone so interview times could be set according to the schedule of the participant. All interviews were conducted in the homes of the study participants. The interviews were conducted by two-person interviewer teams, usually a man and a woman, and each interview lasted approximately one-and-a-half to two hours. Participants were asked open-ended interview questions from a uniform set of interview questions (see Appendix A for interview schedule). The fathers were encouraged particularly to share stories and specific experiences of caring for their children and the meaning of these experiences to them. All of the interviews were tape-recorded and transcribed. Although the interview protocol allowed for asking fathers about both positive experiences and challenges in their father-child relationships, the data presented here are limited to a focus on fathers' descriptions of connecting with their children in positive or affirming ways.

Interview material was condensed into distinct narrative accounts that could be studied (Miles \& Huberman, 1994). Each distinct narrative account analyzed in the study consisted of a specific experience shared by the father in a personal story of lived experience and related contextual material or attached meaning. The narratives were organized first by coding them according to a descriptive code created from the concepts in the conceptual ethic of generative fathering (such as "Care," "Connect," or "Communicate)." This allowed each narrative to be placed under a core theme for analysis, and narratives identified with the "Connect" code were organized for further analysis. Then a second level of more intensive coding occurred that focused on discerning broad, repeating themes or patterns in the narratives. This process involved constant comparison of similarities, themes, and differences among the narratives in each category. From this process pattern codes were created that reflected the primary themes shared by fathers across their narrative accounts in describing their experiences in caring for their children. Data analysis was conducted by a four-person research team of faculty and graduate students that coded the narratives individually and then compared coding efforts across the team members.

\section{FINDINGS REGARDING CONNECTION IN GENERATIVE FATHERING}

Connecting with children in generative fathering refers to the formation of healthy and lasting relational bonds with the child (Dollahite et al., 1997). This encompasses both establishing a good interpersonal relationship with children and fostering understanding and love in the parent-child relationship. Seventy-three narratives were identified and grouped under the descriptive code connect in the study analysis, then examined and compared to discern patterns in how fathers described connecting with their children (both with and without special needs) in various ways. Five central themes emerged in the study related to how fathers describe connecting with their children. These primary themes included fathers connecting with children through (a) personal involvement in shared activities with children; (b) expression of support and care to ill or anxious children; (c) interaction with children at birth (or adoption); (d) shared exchanges of time and affection with children; and (e) participation in spiritual activities with children. The findings shared here present the key 
patterns identified in the narratives and some implications for a conceptual understanding of how fathers connect with children.

\section{INVOLVEMENT IN SHARED ACTIVITIES WITH CHILDREN}

The most significant pattern in the narratives associated with connecting to one's children focused on being personally involved in activities with a child. More than half of the narratives coded in this category illustrated this pattern. The type of activities that fathers described participating in with children also fell into a number of distinctive themes, which are represented below as subthemes in this pattern. The findings showed that fathers described connecting with children through spending meaningful time together in (a) activities of recreation (e.g., camping, hunting, picnicking), (b) activities of play or learning (e.g., hide-and-seek, checkers, word and (c)? games), (c) activities of work or attending important events. Of particular interest was the fact that the sense of connection described by fathers for each of these activity types reflected something slightly different. The most common types of activities cited by fathers occurred in the order given above, respectively, and at times there was some overlap between these categories. The differing dimensions of this primary theme are briefly outlined and highlighted by examples from the fathering narratives.

Fathers who described personal involvement in shared activities with children most commonly specified activities of recreation that included camping, hunting, fishing, and picnicking. Fathers described engaging in these activities more often with sons than daughters, but the study is not designed to determine whether this represents any meaningful gender difference. The sense of connection in these descriptions expressed the theme that connecting with one's children involves time spent in activities together that offer a sense of companionship and enjoyment (often recreational). A distinctive component of this pattern centered on the recreational nature of the activities and the focus on relaxing and having fun with each other. These activities, often occurring outdoors, offer both relaxation and intensity at different times. This seems to make possible both periods of companionship (e.g., sitting around a fire together) and moments of shared enjoyment (e.g., catching a fish together). One father shared his experience in such a shared activity with his daughter:

Janice is the product of a previous marriage of Patrice's and is not my biological daughter, so I came into her life when she was about two years old. I remember the three of us going to [a park] when she was that age. They've got a little carnival there with rides. This particular day we went there and just had a ball, just had a lot of fun. We go skiing now, and that's very enjoyable, but among experiences that I sit back and think about that bring joy to me, that one is one of the best ones. It was really good for me because we were first developing our relationship at that point. That brought us closer together. I enjoyed being with her and watching her.

The father's sense of enjoyment from this experience is clear as he describes that he "enjoyed being with her and watching her." Additionally, he indicates the meaning 


\section{BROTHERSON et al.}

of the connection he experienced through this activity with his daughter was that it "brought us closer together" in their developing relationship and remains a source of joy as he recalls it. Another father mentioned the impression such an activity made when he recognized its importance to his son:

I mostly think of the little times, such as when he wanted to play soccer and we went over and played soccer a while. Afterwards he just kept talking about all the things that he learned playing soccer. He really talked about it for a long time, and so it really made me think, "Boy, that must have been a neat experience for him." To me that is nurturing, spending time and doing things so that it is a meaningful experience for him.

This father's realization of his son's positive reaction to playing soccer together suggests the value of such activities in building a relationship. In talking about the meaning of this experience, he contrasted it with reaching the end of the day after being highly busy and thinking to himself, "Boy, I didn't spend any time at all [with the kids]." Participation in such shared activities that involve recreation thus seems to provide a natural context for meaningful connection. This may often involve being responsive to a child's suggestion for an activity. One father noted of his young daughter, "She might say, 'Daddy, will you come play dolls with me?' What can I say? I go play dolls with her." Shared activities that involve recreation can provide a fun, interactive context for fathers and children to feel companionship and mutual enjoyment that strengthens interpersonal bonds.

A second pattern related to fathers' descriptions of involvement in shared activities with children centered on activities focused on play or learning that allowed for some form of teaching or learning of skills. The sense of connection in these descriptions suggested the idea that connecting with one's children involves being together in activities that enable mutual involvement and interactive learning. A distinctive component of this pattern centered on the instructional nature of the activities and the focus on teaching or involvement in settings of play or learning. Such activities might include teaching a child a song or playing a board game or learning a sport such as baseball. These activities foster the opportunity for teaching and learning to take place because they encourage direct interaction between the individuals involved (e.g., learning to play checkers). A father who taught his young son a song described the experience:

When [Joseph] was about two years old and we were living in Pittsburgh, I was home babysitting. It must have been Saturday. Kim and our other children were off somewhere, and he and I were playing. I taught him and he learned the hand expressions to the song "Popcorn Popping on the Apricot Tree." He and I sat and sang and played that all afternoon on that day. It took all afternoon, but he did learn, and by the time his Mom got home he knew it. It was pretty amazing. He has no recollection of that at all, but for me that is the most enjoyable experience that I can think of with him. 
This father's account highlights in detail the sense of connection he felt when interacting with his son and observing his efforts to learn. Although he uses the colloquial term "babysitting," the father's narrative suggests a warm and involved parenting style, and the term perhaps does not reflect the relationship pattern. It does indicate that men may often still perceive direct caregiving as a secondary role in their parenting even if their activities reflect a more primary effort. This particular father, when asked about the meaning of this experience, recounted that his infant son had focused on his mother during the first year of life but that this experience "was just a time when I was getting closer to him and feeling close to him, so that has a lot of significance." In another account, a father shared a teaching opportunity with his son who struggled with a speech challenge:

When Tyler was growing up, he had a small speech impediment. He had difficulty with his vowel sounds. I think that he was about five and was about in kindergarten and said something like, "I have a problem talking." So we did a little phrase from a song about "Don't Mess with Mr. In-Between" that was, "Accentuate the positive, eliminate the negative," and those were the sounds that he was having trouble with. We taught him to use those sounds in the phrase, and as he would say them his little difficulty with stuttering went away. That helped him with his vowel sounds.

This encounter allowed the father to teach his son a helpful way to overcome his speech difficulty, and in the process he felt closer to him as he watched learning take place. The father commented that the meaning of this experience rested in feeling close to his son because he had been able to help him through gentle teaching. These examples suggest that activities based on mutual involvement can foster learning and enrich the connections between fathers and their children.

A third area of fathers' involvement in activities with children focused on working together or attendance at important events. Fathers reported working with their children in family-owned businesses or watching their children at football games or graduation events. The sense of connection communicated in this pattern was that connecting with one's children involves participating in or observing activities that allow for assisting and seeing children grow and mature. These types of activities allow fathers to observe a child's efforts, struggles, and successes in growing up. Working together provides a context for skills and values to be taught and for children to develop responsibility (e.g., learning to care for the yard). Observance of a child's important events lets a parent communicate a sense of support and esteem to the child (e.g., seeing a child graduate). One father who built homes shared this account:

Probably one of the most enjoyable experiences I had with Tim was when I built my mother-in-law's home, which is just across the street. He was only two or two and a half at the time, and he 


\section{BROTHERSON et al.}

had to be there with me the whole time. It wasn't enough for him to be there, but he had to be doing the same thing that I was doing. You try to appease him by getting him the plastic tools ... no, it won't work. So I had to go and get him smaller but real tools. If I was pounding a nail, he had to pound a nail. Tim had some painful lessons! He had to learn that when you bring the hammer up you don't bring it up and hit your head before you take it back down. But, at two and a half, Tim can pound a 16-penny nail. You've got to start it for him, but he'd stay right there until he got that nail down. To this day Tim likes to work. As long as he can work with Dad, that's fine.

This father's proud comment that "at two and a half Tim can pound a 16-penny nail" reflects his appreciation of his son's accomplishment. He expressed a poignancy about the meaning of this experience of connection, reflecting how each day this son asks him about going to work and then asks, "Do you need any help?" In this exchange he sees the evolution of his son from a boy to a man of responsibility. The feeling of connection expressed is rooted in the father's appreciation of his child's effort and growth. Such descriptions suggest the sense of fulfillment a parent can experience in seeing a child grow and learn in the context of work, school, or other areas of life.

\section{SUPPORT FOR ILl OR ANXIOUS CHILDREN}

A second primary theme in fathers' descriptions of connecting with their children was associated with providing support to a child in difficult circumstances. In this context fathers described connecting with children while expressing support and giving care at times of illness, anxiety, death, or other concerns prompting a need for togetherness. Fathers in the study shared numerous examples of this pattern as it occurred during hospital care, the passing of a loved one, or in other trying situations. An interesting element of this pattern was that the sense of connection was generated bidirectionally: from father to child and from child to father. For example, in one situation a child was required to go into the hospital for an operation, and the father described feeling a responsibility for and connection to the child in this moment of stress. At another time a father lost his own brother, and his child initiated giving comfort to him, and he felt a sense of connection in receiving that support.

Times of stress or difficulty are often more likely to prompt a need for togetherness and support, and this may have been particularly common in this sample, which included fathers with at least one special needs child. One father described how caring for his newly adopted daughter from Russia on a long plane flight instilled a sense of connection:

Coming home on the plane, you could imagine what it was like. We were supposed to have a nonstop flight from Moscow to New York. But thanks to the U.S. Embassy in Moscow, we got to spend three extra days in Russia waiting for them to clear our papers. So 
we had to redo all our flights, and then we ended up having to go through Frankfurt, laid over in Frankfurt, then we had to fly to JFK. We had five hours in JFK, and you can imagine 24 hours on airplanes and in airports with a two-year-old that you can't speak to. She was really pretty good, but we were dead tired, and she was tired, cranky, and hungry. Finally, on the flight from JFK to home, she fell asleep in my arms, and we slept on the way. Just being able to hold her while she slept was really a bonding moment for me. Those times when she comes to me for comfort or wants to be cared for are special.

Such periods of stress often highlight the dependence needs of children and trigger specific opportunities for parents to respond to and connect with their children. This father notes the special bonding that can occur for fathers and children in this context. He reflected that despite having a father and brother who were not emotional or very affectionate, this and similar experiences have "made me more involved in all my kids' lives" and "less harsh in the way I deal with my children." This suggests that connection in such circumstances may help some fathers to develop attitudes and behaviors that can further enhance their relationships. In another case, a father whose special needs son was in the hospital for care shared both the pain and closeness that occur when caring for an ill child:

I think that probably the hardest [time] was one night up at the hospital. He'd been up there quite a while and was just in massive pain. They'd given him medicine, and that didn't work. I held him. Nothing I could do would help him or stop the pain. I guess that just the thought I couldn't take away the pain and that he'd been there so long for so many operations was hard for me. They were pumping him with this antibiotic that made his veins collapse, so they continually had to keep putting it in new areas. [My wife] had told me that they'd spent an hour trying to get it in one time. It would collapse, or they couldn't get the vein. All of those things were running through my mind, and it was just very emotional for me. There's a good side to seeing your son go through pain, which is that you feel compassion for him, and so it is a lot easier for me to be patient when he keeps crying and crying. That really helps a lot - the feelings of compassion I've gained from seeing him go through so much.

While expressing his sense of frustration at not being able to do all that he could in a difficult circumstance, this father also described how caring for a child in such conditions can forge feelings of compassion and a strong sense of connection. The context of giving support in difficult situations seems to provide a meaningful pathway for fathers to experience a strong connection with their children. 
BROTHERSON et al.

\section{INTERACTION WITH CHILDREN AT BIRTH}

The birth experience emerged consistently in the analysis as a common context that offered a deep connection between father and child. This also included adoption. A primary theme was identified in which fathers described strong emotional feelings and a connection with children upon the child's birth or adoption. In this pattern fathers described connecting with children through interacting with a child at birth (or adoption) and feeling close to him or her, particularly in providing care and comfort to the infant. Caring directly for one's newborn child can instill a deepseated connection for a father. One father shared his first experience of holding his disabled son:

Probably one of the most enjoyable moments in our experience with McKay, although they are short right now, was being able to hold him for the first time. He was born with his disabilities in the hospital, and it was five weeks after he was born before we were able to hold him for the first time. That's real tough. . . . You can't hold them, and you think, "How will I be able to do it? How can I catch up?" It happens, but being able to hold him that first time was just a tremendous experience, for us as a family and for me as a father. Holding a hand and patting a back is one thing, but to cradle a newborn life into your arms that you know is yours and that you created, which you've been waiting to do for five weeks - you can't describe it. You don't want to put him down. You don't want to let him go. I finally got to hold you, and I'm going to take care of you.

The father's description of this moment captures its strong personal impact and the emotion of holding a child at birth. Another father, commenting on the birth of his daughter and its meaning for him, said he felt and "learned that from this moment on we will be linked forever" and that "this child is my responsibility forever." The poignancy of such moments described by fathers is a stark contrast to the image of earlier fathers who were relegated to the waiting room or often barred from being present at a child's birth (Parke, 1996). A father who was present at his daughter's birth told this experience:

When Eva was born, she came out screaming mad, and she wasn't going to calm down. We bathed her and wrapped her in clothes and did all the things that you're supposed to do, but she wouldn't calm down. She was mad and didn't want to be out here. It was at a birthing center, and so we actually just stayed there. She was born late at night, and we just stayed there through the night. After my wife was all taken care of and Eva was bathed, dressed, and wrapped in a blanket, we turned off the lights and just wrapped her up tight. She calmed down, and I just held her. I laid down on the bed and just held her all through that first night, and from that moment on she has just been a joy. 
Such feelings of connection to an infant may assist the father to be more attentive to the nurturant care an infant requires early in its development. Such feelings may also pave the way for a father to nurture a commitment to the generative care a child deserves throughout its growing-up years. While early experience does not in any way guarantee commitment through a child's growing years, perhaps initial experiences of connection can assist fathers in taking steps toward assuming parental responsibility.

\section{EXCHANGES OF TIME AND AFFECTION WITH CHILDREN}

Fathers in the study described a variety of "connecting moments" in their narratives that were based upon joyful, positive, meaningful exchanges that they experienced with their children. This pattern involved fathers connecting with children through shared exchanges of time, affection, and emotion in varying contexts. There was a particular difference between this pattern and the pattern of shared involvement in specific activity types (recreation, learning, work, etc.) described earlier. This pattern focused on the process and feelings involved in a mutual exchange of time and affection between father and child in many contexts, while the former pattern centered on the context of involvement in certain domains of activity with a child. Fathers described many of these connecting moments marked by fun, laughter, affection, and meaningful sharing.

These moments shared by fathers seem to exist as windows of time in which the distractions of a hurried schedule or busy lifestyles are blocked out and they can focus on feeling close to their children. For example, one father described this interaction with his daughter:

The most enjoyable experience [with my daughter] is when she comes up and snuggles with me on the couch. She'll just come up and sit by me and put her head on my shoulder. She won't do anything else; she just wants to snuggle and be close. I think that's the most enjoyable time I have. It happens quite regularly.... I just feel closer to her, and I know that she feels close to me. It makes you feel warm inside.... Sometimes we'll talk, and sometimes we won't. I think that just being there is the important part. We could be watching a movie or doing anything.... I think that there's really love there.

The emphasis in this father's description is on the feelings of connection and closeness in that moment rather than the activity. Another father shared this daily moment with his son:

The best thing that I have with John is when I come home from work and he comes flying upstairs yelling, "Daddy, Daddy!" $\mathrm{He}$ always takes my Pepsi and sips on it. But he does that every day, and that's probably the most enjoyable. I'll come home, and he'll just come flying up to me. 


\section{BROTHERSON et al.}

Again this father describes a moment that is meaningful because of the exchange of affection or time. Recently scholars have noted the "time bind" placed on families and the challenges of making time for meaningful family experiences in a culture of haste and hurry (Daly, 1996a; Doherty, 2000; Hochschild, 1997). In a society that increasingly demands the time and attention of parents, these connecting moments in a father-child relationship gain greater importance and suggest the value of the "little

\section{PARTICIPATION IN SPIRITUAL ACTIVITIES WITH CHILDREN}

A final prominent pattern developed in narrative accounts by fathers centered on paternal involvement in spiritually based encounters with children. In these encounters, fathers described connecting with children through participation in specific spiritual activities together (prayer, etc.). It is likely that the prominence of this pattern was associated with the high proportion of study participants who were devout participants in a particular religious background (Latter-day Saint) that encourages responsible fathering (Dollahite et al., 1998; Marks \& Dollahite, 2001). However, it is also consistent with the suggestion that religious or spiritual motivation can provide a "powerful, meaningful, and sustained influence for encouraging men to be fully involved in children's lives" (Dollahite, 1998). Fathers shared a number of accounts in which they expressed a strong feeling of connection to children when assisting them in spiritual exercises or providing spiritual guidance.

One father discussed the emotional connection he feels with his young son in saying prayers together at bedtime each night:

When we go say prayers at night or play football in his room upstairs, I feel that connection. Probably just saying prayers with him every night, because I always go up and say it with him. Now he starts jabbering and saying them a little bit. It's neat because we'll sit there, and then he'll fold his arms and lean his head on my shoulder - then Dad starts getting emotional. It's just that he'll always think when he goes to bed that he has to have Dad say his prayers with him. Hopefully, he'll do that with his kids. I hope he does. It's hard to explain. I only said prayers with my dad a couple of times, as it was always with my mom, but I think that would have been neater if it had been my dad.

Prayer is a common spiritual activity, and in this account it furnishes a positive context for a father's sense of connection and responsibility. Other accounts included such spiritual activities as service to others, worship, prayer, or participation in spiritual rites. Such practices may at times provide a connecting pathway for fathers to be meaningfully involved with their children and contribute to a child's growth and guidance.

Fathers who participate in spiritual activities with their children gain the opportunity to nurture the transmission of held values and help their children in times of 
need or anxiety. A father whose daughter was ill with leukemia and died shared this poignant and powerful moment:

I got to be there. We knew it was coming, and the nurse had told us that the last thing to go is eyesight and hearing. So [my wife] was right down at her ear, just talking in her ear and telling her how proud we were of her and how she'd done things just right, and she was going to be okay and we were looking forward to seeing her again some time ... just all the wonderful things that we could think of to say. I sat there and held her hands, and she was looking at me, and I just watched her slowly fade away. It was the most peaceful, and I hate to use this word, but it was one of the most wonderful experiences. There are many people who had children kidnapped or murdered, and in what I got to experience, though I did not enjoy losing Megan and didn't want to lose Megan, I got to be there, and I got to hold her hand, and I got to look into her eyes as she faded away. It was really a special and a close moment.

This father's account suggests the deep sense of connection that a spiritual moment between father and child can provide. Of course, this account of a child's death is uncommon and atypical, yet it reveals the value of a father's presence and sensitivity in a spiritual context.

\section{DISCUSSION OF FINDINGS}

These findings suggest the central function of connecting with a child in the relationship processes that occur in a father's interactions with his children. They also highlight the unique and highly contextual nature of some aspects of connecting with a child. The examination of fathers' narratives to discover central patterns of interaction among fathers and children allowed for both expanding the dimensions of connecting with one's child as a father and developing pragmatic insights into this process.

The primary focus of this study was to utilize the generative fathering perspective as a lens to view how a particular group of fathers describes the experience of connecting with their children. This approach offered the possibility of learning the essential components of connecting with a child for some fathers and the particular relationship contexts that can foster such connection for fathers and children.

One of the potentially useful contributions of this study is the conceptualization of father-child connection as a key element of generative fathering that is grounded in fathers' descriptive experience. For fathers in this study, the experience of being connected to a child occurred across multiple circumstances and seemed to consist of several essential components. In general, the concept of connection as mirrored in these fathers' narratives can be understood as a broad concept that emphasizes the sense of a tangible interpersonal tie between father and child. The varying patterns of connection described by fathers in this study provide a starting point for further 


\section{BROTHERSON et al.}

exploration of connection as a theoretical construct, although it is only a starting point. The authors compared the patterns identified in this study and examined them to discern whether any common elements existed across all of the different patterns of connection that were identified. This was done to develop a starting point for thinking about connection as a specific conceptual construct. This brief analysis suggests that some essential components of father-child connection as described in these fathers' experiences include (1) a feeling of emotional and psychic connection to the child; (2) a context of meeting a child's developmental needs for care or guidance; (3) personal interaction centered in support or activities together; and (4) the practice of generative care by the father toward the child. These elements can be found in common across the wide variety of patterns that these fathers described in connecting with their children. Thus the experience of connecting with a child was expressed in situations ranging from quiet conversation to playful wrestling to teaching a child to pound a nail. We do not propose further discussion of these elements here but simply suggest that they may provide a useful starting point for later exploration of connection as a theoretical construct.

The relevance of connecting with one's child as a primary feature of fathering receives support from other research studies as well. Pleck (1997) has highlighted the importance of positive paternal involvement in father-child relationships, and Lamb (1997) suggests a need for further attention to the "emotional quality of father-child relationships" (p. 6). Research on adolescent socialization has shown a sense of connection between parent and child to be a powerful predictor of child adjustment and well-being (Barber, 1997). These findings are further illuminated by recent research from the National Longitudinal Study of Adolescent Health, which demonstrates that "connectedness to parents/family" is a significant protective influence for adolescents in decreasing risk behaviors (Resnick et al., 1997). Finally, father-child connection has recently been shown to have a positive and significant influence on father-child relationship quality and adolescent child well-being (Brotherson, Yamamoto, \& Acock, 2003).

There is a substantive difference between illuminating the relevance of a developing conceptual construct and suggesting a fully differentiated theoretical construct that is distinctive from other fathering constructs. This paper represents a "mapping of the territory" related to the concept of connection in generative fathering rather than an argument that completely articulates a theoretical development of the construct of connection. Hawkins and Palkovitz (1999), in a call for more diverse and broader conceptualizations of father involvement, suggest that such efforts will benefit from "a focus on the nature and experience of [fathering] activities themselves" and also "knowledge about how caregivers experience that time" (pp. 13, 22). The suggested central elements of connection described above share elements with other constructs in the fathering or parenting literature. This initial mapping, however, represents a step forward in understanding elements of connection as described by fathers themselves. It also opens the door to the further refinement of this construct and the exploration of linkages between connection and other constructs. For example, attachment is the concept used to refer to the relationship developed between an infant and a parent or primary caregiver during the early years of life, and its quality is dependent on how a parent responds to a child's needs for care, comfort, and 
security (Bowlby, 1982). Connection as articulated here also occurs in the context of meeting a child's developmental needs for care and guidance. The findings from this study provide more impetus for emphasizing the positive role of connection in father-child relationships and a beginning point for further theoretical conceptualization of this concept. It may be that the patterns of interaction that facilitate connection are primary contexts for children and fathers to develop a secure attachment relationship. Also, the sense of emotional bonding that seems to characterize connection for fathers may be important in facilitating his responsiveness to a child's needs. The findings also suggest the heuristic value of connecting with one's children as a key element in the relationship work domain of generative fathering (Dollahite et al., 1997). These types of conceptual linkages remain to be further developed in subsequent work on this topic.

The specific patterns of father-child connection affirmed in this study denote pragmatic examples of how some fathers experience connecting with their children. Though clearly not exhaustive, these primary themes do furnish substantive insights regarding how these particular fathers connect with their children.

The most prominent pattern in the fathers' narratives suggested that fathers connect through personal involvement in shared activities with children, particularly activities that involve recreation, play or learning, or working together. The prevalence of this pattern in the narratives suggests that fathers may connect with children best in a semi-structured environment of shared activity that allows for physical interaction and sharing of mutual interests as well as personal conversation. Fathers generally expressed connection to children when participating in activities of one kind or another with children. This type of interactive involvement seemed somewhat more important to fathers than emotional disclosure. This pattern is consistent with Pleck's (1997) observation that quantitative measures of father involvement are increasingly designed to "ascertain level of involvement through assessing activities that are not just indicators of overall time spent with the child, but are specific activities likely to promote development" (p. 68). Pleck (1997) suggests the "dimension of paternal behavior that actually should be of primary interest" (p. 102) is the content of a father's involvement, what he describes as positive paternal involvement. The activity patterns outlined in this study are consistent with Pleck's suggestion and open a window into the specific ways that fathers connect with their children.

Another prominent theme in the narratives was that many fathers connect with their children at times of giving care or support when there is illness, anxiety, or some other type of stress. The initial onset of stress when a child is ill or in need can be highly stressful to fathers, but research suggests that most fathers tend to adapt maturely (Lamb \& Meyer, 1991). Due to the number of children with special needs in this sample, it is likely that the number of needs-based caring examples shared by fathers was higher than is typical. Dealing in a direct and caring way with such daily challenges has been cited as a major theme in fathers' care of special needs children. Such circumstances of stress tend to engage fathers in caring behavior that involves "daily responsiveness to a child's immediate and changing needs" (Dollahite et al., 1998 , p. 80). This pattern also suggests that these fathers continue to fulfill the protective role associated with fatherhood historically in many contexts (Griswold, 1993; Pleck \& Pleck, 1997). 
BROTHERSON et al.

A significant pattern in the narratives involved fathers connecting with children through interacting with a child at birth (or adoption) and experiencing a sense of closeness to the infant, especially in giving care or comfort. There is perhaps no human interaction that requires meeting another's needs so directly as the entrance of a child into the world. Research on fathers' experiences at the birth of a child shows that 88 percent of those not present feel negative about missing the experience while 95 percent of those fathers who participate feel positive about it and many report it as a "peak" emotional experience (Entwisle \& Doering, 1981). Parke (1996) has suggested, "In view of the real possibility that early contact with babies may strengthen feelings of fatherhood, being present at the delivery may facilitate later involvement with the child" (p. 33). In essence, these "connecting moments" early in a father's experience with a child may provide a "jump start" on their learning and motivation to be a competent father (Cowan \& Cowan, 1992; Palkovitz, 1985). The context may be birth, adoption, or later moments of interaction, but what seems important is that such contexts provide a commonly appreciated pathway for fathers to experience initial feelings of connection with a child. Elements of this context in the study that seemed to make it stand out as an opportunity for establishing connection included the father's awareness of the child's dependence, holding or taking care of the child directly, and a sense of spiritual or emotional connection to the child.

Two final themes of significance in the study, connecting with children through moments of shared time and affection or through spiritual activities, highlight the diverse contexts in which father-child connection may occur. The first pattern centered in shared exchanges of time, affection, and emotion between fathers and their children. Call (2002) has suggested that what she calls "prosaic behavior . . the common, ordinary, simple parts of their relationships with children" (p. 16) is crucial to the experience of connection in father-child relationships. This is suggested as being particularly true for noncustodial or divorced fathers, who may tend to miss out more often on such common moments that allow for connection to occur (Pasley \& Minton, 1997). Daly (1996b) has found that time together is central to fathers' understanding of the possibility of such meaningful moments of connection with their children. This pattern in the findings suggests that at times it is the process of the experience that is more important to father-child connection than the particular experience itself. Specific types of activities can be meaningful, however, as seems true in this study with involvement in spiritual activities.

The additional pattern of connecting with children through spiritual activities emphasizes the religious nature of the sample but also illuminates a substantive dimension of fathering for many men. Recent research has highlighted the importance of spiritual activities for many men in their fathering efforts and provided insight into a context of fathering connection that holds strong meaning for many fathers and families (Canfield, 1996; Dollahite, 2003a). Dollahite (1998) suggests that fathers who seek to provide children with meaning, direction, and solace often do so through participation in "religious beliefs, practices, narratives, and communities" (p. 7). Many systems of religious belief provide specific opportunities for parent-child involvement in spiritual activity designed to strengthen relationships and reinforce moral lessons. The findings of this study suggest that participating in 
prayer, blessing rituals, worship, or other spiritually centered activities can facilitate meaningful connecting opportunities between fathers and children.

It is important to note that while this study furnishes some groundwork for understanding the dynamics of connection in the relationship work domain of generative fathering, it is also limited in scope and requires further substantive research. Unique features of this sample, including the inclusion of children with special needs and the religious context of the study participants, necessitate modesty in applying these research findings to other populations. The presence of these two characteristics is likely to have elicited more narrative accounts that highlight the dynamics of father-child connection. For example, the context of caring for a special needs child probably influenced the finding that connection takes place in caring for an ill or anxious child. Also, the involvement of men who are part of a religious community that values family relationships may have generated more examples of participation in spiritual activities with children. Yet while application of these findings to all fathers is not possible, they do furnish insight into how some fathers describe their experiences in connecting with their children, and they suggest how the shaping influence of characteristics such as a special needs child or religious motivation might emerge in understanding the dynamics of father-child connection. It should also be noted that these findings derive from the fathers' perspective on their experiences in the parent-child relationship and do not include accounts from the children's perspective. Further research efforts in this area will benefit from designs that incorporate both fathers' and children's perspectives on experiences that facilitate connection between them. However, the findings do suggest the primary role of connecting with one's child for these fathers. It seems reasonable to suggest that such a pattern is likely among other father-child relationships and that the dynamics of father-child connection should be explored in more diverse samples across race, religion, socioeconomic status, family structure, and other contexts. Such efforts will make possible greater understanding of connection as it occurs between fathers and children and how it might be applied in practical contexts.

\section{IMPLICATIONS OF THE STUDY'S FINDINGS}

The implications of this study, while modest, provide several useful directions to consider in the study of father-child relationships and generative fathering.

First, the recent introduction of generative fathering as an alternative conceptualization of father-child relationships suggests the possibility of its use both to frame research questions and guide research analysis. This study utilized the relationship work domain of generative fathering and the perspective's grounding assumptions to examine how fathers connect with their children in varying circumstances. The findings suggest that, beyond its conceptual value, the construct of connecting with one's children does function as a central feature of relationship work in generative fathering. Scholars interested in father-child relationships may benefit from further examining the role of father-child connection and its linkage to generative fathering or other theoretical models such as positive paternal involvement (Dollahite et al., 1997; Pleck, 1997). 


\section{BROTHERSON et al.}

Second, the limited nature of this sample argues for the need for further indepth research on the dynamics of father-child connection with varying populations and across differing circumstances. While it seems likely that the central patterns in this study will apply in some other contexts, this study also showed that some instances of father-child connection may be quite context-sensitive (religious settings, children with special health needs, etc.). Further research with other populations can allow for the development of greater insights into father-child connection as a general construct while also highlighting the particular contexts in which fathers connect meaningfully with their children.

Finally, there is a continuing need for research that emphasizes practical findings to apply for those doing clinical or educational interventions to strengthen the father-child relationship. Fagan and Hawkins (2001) point out, for example, that "professionals in the field are beginning to understand that specialized areas of knowledge are needed to work successfully with fathers" (p. 5). They also indicate that research is just beginning to emerge that describes best practices or areas of content for working with fathers. The findings from this study offer practical insights for scholars and practitioners who wish to understand how some fathers connect in meaningful ways with their children. Specific ideas that educators, counselors, or others might utilize to apply these findings in their work with fathers and families include the following.

- Programs serving fathers and children might examine their program activities and assess what they do specifically to actively facilitate connection between fathers and children.

- Parent and family education efforts aimed at fathers or father figures might include a focus on implementing activities with children that facilitate connection through involvement in shared activities of mutual interest-such as playing games or hiking or outdoor activities.

- Parent and family education efforts might highlight the significance of contexts that seem to enhance the possibility of connection between father and child when care is given, including care when a child is ill or anxious, initial encounters such as birth or adoption, small exchanges of time or affection, or participation in spiritual activities.

- Practitioners in clinical settings might examine the family relationships for the presence or absence of healthy connecting activities between fathers and children and identify barriers to such connecting moments and opportunities that might be increased.

- Practitioners might work with fathers and children who may have family challenges to understand and identify specific activities that might help to develop or sustain connection in their relationships.

Such findings can be adapted to be taught in parent or family life education settings, fathering groups, faith-based arenas, or other avenues for reaching fathers and families. Effective work with fathers is more likely when informed by fathers' particular experiences as parents and the way they perceive their interactions with children (Fagan \& Hawkins, 2001). 
GENERATIVE FATHERING

\section{CONCLUSION}

As a lens for understanding how a particular group of fathers describes the work of connecting with the children in their lives, the generative fathering perspective offers a unique and context-sensitive approach to understanding the dynamics of connection between fathers and their children. This study illustrates that particular patterns and behaviors exemplifying the relationship work of generative fathering can be found in narrative accounts told by fathers of their experiences connecting with children. This research has been meant to explore fathers' experience from within their own perspectives and to respect the personal voices and lived experience, which exist in their personal narrative. Their voices share a message of positive possibilities for fashioning healthy experiences of connection between fathers and children.

\section{REFERENCES}

Ahlander, N., \& Bahr, K.S. (1995). Beyond drudgery, power, and equity: Toward an expanded discourse on the moral dimensions of housework in families. Journal of Marriage and the Family, 57, 54-68.

Ainsworth, M.D.S. (1973). The development of infantmother attachment. In B.M. Caldwell and H.N. Ricciuti (Eds.), Review of Child Development Research, Vol. 3 (pp. 1-94). Chicago, IL: University of Chicago Press.

Ainsworth, M.D.S., Blehar, M.C., Waters, E., \& Wall, S. (1978). Patterns of attachment: A psychological study of the strange situation. Hillsdale, NJ: Lawrence Erlbaum Associates.

Amato, P.R. (1987). Children in Australian families: The growth of competence. New York: Prentice-Hall.

Barber, B.K. (1992). Family, personality, and adolescent problem behaviors. Journal of Marriage and the Family, 54, 69-79.

Barber, B.K. (1997). Adolescent socialization in context: The role of connection, regulation, and autonomy in the family. Journal of Adolescent Research, 12(1), 5-11.

Berger, P., \& Kellner, H. (1994). Marriage and the construction of reality: An exercise in the microsociology of knowledge. In G. Handel \& G.G. Whitchurch (Eds.), The psychosocial interior of the family (4th ed., pp. 19-36). New York: Walter de Gruyter.

Biller, H.B. (1993). Fathers and families: Paternal factors in child development. Westport, CT: Auburn House.

Blankenhorn, D. (1995). Fatherless America: Confronting our most urgent social problem. New York: BasicBook.

Bowlby, J. (1982). Attachment and loss: Vol. 1. Attachment (2nd ed.). London: Penguin Books.

Bretherton, I. (1985). Attachment theory: Retrospect and prospect. In I. Bretherton \& E. Waters (Eds.), Growing points of attachment theory and research. Monographs of the Society for Research in Child Development, 50 (1-2, Serial No. 209).

Bretherton, I. (1987). New perspectives on attachment relations: Security, communication, and internal working models. In J. Osofsky (Ed.), Handbook of infant development. [need complete citation] 
BROTHERSON et al.

Brotherson, S.E., \& Dollahite, D.C. (1997). Generative ingenuity in fatherwork with young children with special needs. In A.J. Hawkins \& D.C. Dollahite (Eds.), Generative fathering: Beyond deficit perspectives (pp. 89-104). Thousand Oaks, CA: Sage Publications.

Brotherson, S.E., Yamamoto, T., \& Acock, A. C. (2003). Connection and communication in father-child relationships and adolescent child well-being. Fathering: A Journal of Theory, Research, and Practice about Men as Fathers, 1(3), 191214.

Call, J. (2002). Finding the extraordinary in the ordinary. Marriage and Families, January, 7-18.

Canfield, K. (1996). The heart of a father: How dads can shape the destiny of America. Chicago: Northfield Publishing.

Comanor, W.S., \& Phillips, L. (1998). The impact of income and family structure on delinquency. Working paper in economics No. 795R, University of California at Santa Barbara Economics Department.

Cowan, C.P., \& Cowan, P.A. (1992). When partners become parents: The big life change for couples. New York: Basic Books.

Cummings, E.M., \& O'Reilly, A.W. (1997). Fathers in family context: Effects of marital quality on child adjustment. In M.E. Lamb (Ed.), The role of the father in child development (3rd ed., pp. 49-65). New York: Wiley.

Daly, K. (1995). Reshaping fatherhood: Finding the models. In W. Marsiglio (Ed.). Fatherhood: Contemporary theory, research, and social policy (pp. 21-40). Thousand Oaks, CA: Sage Publications.

Daly, K. (1996a). Families and time: Keeping pace in a hurried culture. Thousand Oaks: Sage Publications.

Daly, K. (1996b). Spending time with the kids: Meanings of family time for fathers. Family Relations, 45, 466-476.

Daniels, P., \& Weingarten, K. (1982). Sooner or later: The timing of parenthood in adult lives. New York: W.W. Norton \& Co.

Day, R.D., \& Lamb, M.E. (Eds.). (2003). Conceptualizing and measuring father involvement. Mahwah, NJ: Lawrence Erlbaum Associates.

Dienhart, A., \& Dollahite, D.C. (1997). A generative narrative approach to clinical work with fathers. In A.J. Hawkins \& D.C. Dollahite (Eds.), Generative fathering: Beyond deficit perspectives (pp. 183-199). Thousand Oaks, CA: Sage Publications.

Doherty, W.J. (2000). Take back your kids: Confident parenting in turbulent times. South Bend, IN: Sorin Books.

Doherty, W.J. (1991). Beyond reactivity and the deficit model of manhood: A commentary on articles by Napier, Pittman, and Gottman. Journal of Marital and Family Therapy, 17, 29-32.

Doherty, W.J., Kouneski, E.F., \& Erickson, M.F. (1998). Responsible fathering: An overview and conceptual framework. Journal of Marriage and the Family, 60, 277-292.

Dollahite, D.C. (2003a). Fathering for eternity: Generative spirituality in Latter-day Saint fathers of children with special needs. Review of Religious Research, 44, 237-251. 
Dollahite, D.C. (2003b). A narrative approach to exploring responsible involvement of fathers with their special-needs children. In R.D. Day \& M.E. Lamb (Eds.), Conceptualizing and measuring father involvement (pp. 109-127). Mahwah, NJ: Lawrence Erlbaum Associates.

Dollahite, D.C. (1998). Fathering, faith, and spirituality. The Journal of Men's Studies, 7(1), 3-15.

Dollahite, D.C., \& Hawkins, A.J. (1998). A conceptual ethic of generative fathering. The Journal of Men's Studies, 7, 109-132.

Dollahite, D.C., Hawkins, A.J., \& Brotherson, S.E. (1996). Narrative accounts, generative fathering, and family life education. In J.F. Gilgun \& M.B. Sussman (Eds.), The methods and methodologies of qualitative family research (pp. 349368). New York: The Haworth Press.

Dollahite, D.C., Hawkins, A.J., \& Brotherson, S.E. (1997). Fatherwork: A conceptual ethic of fathering as generative work. In A.J. Hawkins \& D.C. Dollahite (Eds.), Generative fathering: Beyond deficit perspectives (pp. 17-35). Thousand Oaks, CA: Sage Publications.

Dollahite, D.C., Marks, L.D., \& Olson, M.M. (1998). Faithful fathering in trying times: Religious beliefs and practices of Latter-day Saint fathers of children with special needs. The Journal of Men's Studies, 7(1), 71-93.

Entwisle, D.R., \& Doering, S.G. (1981). The first birth. Baltimore, MD: John Hopkins University Press.

Erikson, E.H. (1959). Identity and the life cycle. New York: Norton.

Fagan, J., \& Hawkins, A.J. (Eds.). (2001). Clinical and educational interventions with fathers. Binghamton, NY: The Haworth Press.

Ferree, M.M. (1991). Beyond separate spheres: Feminism and family research. In A. Booth (Ed.), Contemporary families: Looking forward, looking back (pp. 103121). Minneapolis, MN: National Council on Family Relations.

Gerson, K. (1993). No man's land: Men's changing commitments to family and work. New York: Basic.

Gilgun, J.F., Daly, K., \& Handel, G. (1992). Qualitative methods in family research. Newbury Park, CA: Sage Publications.

Glaser, B.G., \& Strauss, A.L. (1967). The discovery of grounded theory: Strategiesfor qualitative research. New York: Aldine de Gruyter.

Griswold, R.L. (1993). Fatherhood in America: A history. New York: Basic.

Grossman, F.K., Pollack, W.S., \& Golding, E. (1988). Fathers and children: Predicting the quality and quantity of fathering. Developmental Psychology, 24, 82-91.

Harper, C.C., \& McLanahan, S.S. (1998). Father absence and youth incarceration. Paper presented at the annual meeting of the American Sociological Association, San Francisco, CA.

Harris, J.R. (1998). The nurture assumption: Why children turn out the way they do. New York: Free Press.

Hawkins, A.J., Bradford, K.P., Palkovitz, R., Christiansen, S.L., Day, R.D., \& Call, V.R.A. (2002). The Inventory of Father Involvement: A pilot study of a new measure of father involvement. The Journal of Men's Studies, 10(2), 183-196. 
BROTHERSON et al.

Hawkins, A.J., \& Dollahite, D. C. (1994). Invited essay-book review of No man's land: Men's changing commitments to family and work. Kathleen Gerson. New York: Basic. 1993; Men, work, and family. Jane C. Hood (Ed.). Newbury Park, CA: Sage. 1993; American manhood: Transformations in masculinity from the Revolution to the Modern Era. E. Anthony Rotundo. New York: Basic. 1993; Growing up male: The psychology of masculinity. B. Mark Schoenberg. Westport, CT: Bergin \& Garvey. 1993; and How fathers care for the next generation: A four-decade study. John Snarey. Cambridge, MA: Harvard University. 1993. In Journal of Marriage and the Family, 56(3), 772-776.

Hawkins, A.J., \& Dollahite, D.C. (1997a). Generative fathering: Beyond deficit perspectives. Thousand Oaks, CA: Sage Publications.

Hawkins, A.J., \& Dollahite, D.C. (1997b). Beyond the role-inadequacy perspective of fathering. In A.J. Hawkins \& D.C. Dollahite (Eds.), Generative fathering: Beyond deficit perspectives (pp. 3-16). Thousand Oaks, CA: Sage Publications.

Hawkins, A.J., Dollahite, D.C., \& Rhoades, C.J. (1993). Turning the hearts of the fathers to the children: Nurturing the next generation. BYU Studies, 33(2), 273291.

Hawkins, A.J., \& Palkovitz, R. (1999). Beyond ticks and clicks: The need for more diverse and broader conceptualizations and measures of father involvement. The Journal of Men's Studies, 8, 11-32.

Hochschild, A. (1997). The time bind: When work becomes home and home becomes work. New York: Metropolitan/Holt.

Horn, W.F. (1999). Did you say "movement"? In W.F. Horn, D. Blankenhorn, \& M.B. Pearlstein (Eds.), The fatherhood movement (pp. 1-16). Lanham, MD: Lexington Books.

Hosley, C.A., \& Montemayor, R. (1997). Fathers and adolescents. In M.E. Lamb (Ed.), The role of the father in child development (3rd ed., pp. 162-178). New York: Wiley.

Koestner, R., Franz, C., \& Weinberger, J. (1990). The family origins of empathic concerns: A 26-year longitudinal study. Journal of Personality and Social Psychology, 58, 709-717.

Krampe, E.M. (2003). The inner father. Fathering: A Journal of Theory, Research, and Practice about Men as Fathers, 1(2), 131-148.

Krampe, E.M., \& Fairweather, P.D. (1993). Father presence and family formation: A theoretical reformulation. Journal of Family Issues, 14, 572-591.

Lamb, M.E. (Ed.). (1981). The role of the father in child development (2nd ed.). New York: Wiley.

Lamb, M.E. (Ed.). (1997). The role of the father in child development (3rd ed.). New York: Wiley.

Lamb, M.E., \& Meyer, D.J. (1991). Fathers of children with special needs. In M. Seligman (Ed.), The family with a handicapped child (2nd ed., pp. 151-179). Boston: Allyn \& Bacon.

Lamb, M.E., Pleck, J.H., Charnov, E.L., \& Levine, J.A. (1985). Paternal behavior in humans. American Zoologist, 25, 883-894. 
Lamb, M.E., Pleck, J.H., Charnov, E.L., \& Levine, J.A. (1987). A biosocial perspective on paternal behavior and involvement. In J.B. Lancaster, J. Altman, A. Rossi, \& L.R. Sherrod (Eds.), Parenting across the lifespan: Biosocial perspectives (pp. 11-42). New York: Academic.

Levant, R.F. (1992). Toward the reconstruction of masculinity. Journal of Family Psychology, 5, 379-402.

Marks, L.D., \& Dollahite, D.C. (2001). Religion, relationships, and responsible fathering in Latter-day Saint families of children with special needs. Journal of Social and Personal Relationships, 18(5), 625650.

Marsiglio, W. (1991). Paternal engagement activities with minor children. Journal of Marriage and the Family, 53, 973-986.

Marsiglio, W. (1995). Fatherhood scholarship: An overview and agenda for the future. In W. Marsiglio (Ed.), Fatherhood: Contemporary theory, research, and social policy (pp. 1-20). Thousand Oaks, CA: Sage Publications.

Marsiglio, W., Amato, P., Day, R.D., \& Lamb, M.E. (2000). Scholarship on fatherhood in the 1990s and beyond. Journal of Marriage and the Family, 62(4), 1173-1191.

Miles, M.B., \& Huberman, A.M. (1994). Qualitative data analysis. Thousand Oaks, CA: Sage Publications.

Mosley, J., \& Thomson, E. (1995). Fathering behavior and child outcomes: The role of race and poverty. In W. Marsiglio (Ed.), Fatherhood: Contemporary theory, research, and social policy (pp. 148-165). Thousand Oaks, CA: Sage.

Palkovitz, R. (1985). Father's birth attendance, early contact, and extended contact with their newborns: A critical review. Child Development, 56, 392-406.

Palkovitz, R. (1997). Reconstructing "involvement": Expanding conceptualizations of men's caring in contemporary families. In A.J. Hawkins \& D.C. Dollahite (Eds.), Generative fathering: Beyond deficit perspectives (pp. 200-216). Thousand Oaks, CA: Sage Publications.

Parke, R.D. (1996). Fatherhood. Cambridge, MA: Harvard University Press.

Pasley, K., \& Minton, C. (1997). Generative fathering after divorce and remarriage: Beyond the "disappearing dad." In A.J. Hawkins \& D.C. Dollahite (Eds.), Generative fathering: Beyond deficit perspectives (pp. 118-133). Thousand Oaks, CA: Sage Publications.

Pleck, J.H. (1997). Paternal involvement: Levels, sources, and consequences. In M.E. Lamb (Ed.), The role of the father in child development (3rd ed., pp. 66103). New York: Wiley.

Pleck, E.H., \& Pleck, J.H. (1997). Fatherhood ideals in the United States: Historical dimensions. In M.E. Lamb (Ed.), The role of the father in child development (3rd ed., pp. 33-48). New York: Wiley.

Popenoe, D. (1996). Life without father: Compelling new evidence that fatherhood and marriage are indispensable for the good of children and society. New York: Free Press.

Pruett, K.D. (1989). The nurturing male: A longitudinal study of primary nurturing fathers. In S. Cath, A.R. Gurwitt, \& L. Gunsberg (Eds.), Fathers and their families (pp. 389-405). Hillsdale, NJ: Analytic Press. 


\section{BROTHERSON et al.}

Resnick, M.D., Bearman, P., Blum, R.W., Bauman, K.E., Harris, K. M., Jones, J., et al. (1997). Protecting adolescents from harm: Findings from the National Longitudinal Study of Adolescent Health. Journal of the American Medical Association, 278(10), 823-832.

Seward, R.R. (1994). Determinants of family culture: Effects on fatherhood. In G. Handel \& G.G. Whitchurch (Eds.), The psychosocial interior of the family (4th ed., pp. 211-226). New York: Walter de Gruyter.

Silverstein, L.B., \& Auerbach, C.F. (1999). Deconstructing the essential father. American Psychologist, 54(6), 397-407.

Snarey, J. (1993). How fathers care for the next generation: A four-decade study. Cambridge, MA: Harvard University Press.

Tesch, R. (1990). Qualitative research: Analysis types and software tools. Bristol, PA: The Falmer Press.

Thompson, L., \& Walker, A.J. (1991). Gender in families: Women and men in marriage, work, and parenthood. In A. Booth (Ed.), Contemporary families: Looking forward, looking back (pp. 76-102). Minneapolis, MN: National Council on Family Relations.

Widdershoven, G.A.M. (1993). The story of life: Hermeneutic perspectives on the relationship between narrative and life history. The Narrative Study of Lives, 1, $1-20$.

\section{APPENDIX}

\section{INTERVIEW SCHEDULE FOR GENERATIVE FATHERING STUDY}

Statement: I would like to find out about some of your experiences with (child's name) and what those experiences mean to you.

(1) Can you tell me about the most enjoyable experience you ever had with ? What meaning does that experience have for you now?

(2) Can you tell me about an experience when you felt especially close emotionally to ? What meaning does that experience have for you now?

(3) Can you tell me about an experience when you cared for and nurtured ? What did you learn about nurturing children from that experience?

(4) Can you tell me about an experience when you felt especially distant emotionally from __ when he/she needed you to be there for him/her? What meaning does that experience have for you now?

(5) What was the most painful experience you ever had with ? What meaning does that experience have for you now?

(6) Are there any particular things that help you to be the kind of father to that he/she needs you to be?

(7) Are there any particular things that prevent you from being the kind of father to that he/she needs you to be?

(8) Can you tell me about any important sacrifices you have made in your life that demonstrate how much you care about ? 